\title{
Intrinsic vulnerability assessment of the south-eastern Murge (Apulia, southern Italy)
}

\author{
A. Marsico ${ }^{1}$, G. Giuliano ${ }^{2}$, L. Pennetta ${ }^{1}$, and M. Vurro ${ }^{2}$ \\ ${ }^{1}$ Dipartimento di Geologia e Geofisica Università di Bari, Italy \\ ${ }^{2}$ Istituto di Ricerca sulle Acque, CNR-IRSA Roma-Bari, Italy
}

Received: 2 August 2004 - Revised: 29 October 2004 - Accepted: 10 November 2004 - Published: 22 November 2004

Part of Special Issue "Natural and anthropogenic hazards in karst areas"

\begin{abstract}
Maps of areas with different vulnerability degrees are an integral part of environmental protection and management policies. It is difficult to assess the intrinsic vulnerability of karst areas since the stage and type of karst structure development and its related underground discharge behaviour are not easy to determine. Therefore, some improvements, which take into account dolines, caves and superficial lineament arrangement, have been integrated into the SINTACS R5 method and applied to a karst area of the southeastern Murge (Apulia, southern Italy). The proposed approach integrates the SINTACS model giving more weight to morphological and structural data; in particular the following parameters have been modified: depth to groundwater, effective infiltration action, unsaturated zone attenuation capacity and soil/overburden attenuation capacity. Effective hydrogeological and impacting situations are also arranged using superficial lineaments and karst density. In order to verify the reliability of the modified procedure, a comparison is made with the original SINTACS R5 index evaluated in the same area. The results of both SINTACS index maps are compared with karst and structural features identified in the area and with groundwater nitrate concentrations recorded in wells. The best fitting SINTACS map is then overlaid by the layout of potential pollution centres providing a complete map of the pollution risk in the area.
\end{abstract}

\section{Introduction}

Karst groundwater is of great importance as a resource for water supplies. Unfortunately, it is very vulnerable to human activities since its non-homogeneous three-dimensional structure allows pollution to spread easily.

In order to define the sensitivity of a groundwater system to human impact, both the geological and hydrogeological

Correspondence to: A. Marsico

(antomarsi@geo.uniba.it) characteristics of the area are studied. The assessment of intrinsic vulnerability can be made using several methods, for example DRASTIC (Aller et al., 1987), SINTACS (Civita, 1994), GOD (Foster, 1987), which concern many system factors such as geological setting, underground discharge behaviour, amount of rainfall and protection provided by overburden (Civita, 1994). Nevertheless, the protection of karst groundwater must take into account the specific characteristics of karst aquifer: relatively little filtration occurs because the recharge takes place through enlarged fractures; the flow rate is faster in some parts of the karst than in others; swallow holes allow surface water to have direct access to the conduits (COST 65, 1995). In order to assess vulnerability of the karst aquifer it is also necessary to consider both the stage and type of development of the karst structure and the kind of infiltration - diffuse or point - which characterises it (Doerfinger and Zwahlen, 1998). Others methods have then been developed for karst systems such as EPIK (Doerfinger and Zwahlen, 1998), RESK (Malìk and Švasta, 1999), RISKE (Petelet-Giraud et al., 2001).

Amongst all the methods available, the SINTACS R5 (Civita and De Maio, 2000) was chosen for this study, since it consists of seven parameters measuring typical hydrogeological features and it has been tested in different contexts giving good results. Several authors (Longo et al., 2001; Cimino and Abbate, 1999; Cucchi et al., 2000; Cucchi et al., 2003) have integrated certain parameters of SINTACS methods based on the stage of karst development in order to adapt it better to karst systems. These studies have mainly been carried out by means of spring hydrographs and then by karst feature density measurements. Unfortunately, hydrographs are not available for the Murge area since there is a lack of surveyable springs due to the geological and hydrogeological setting of the plateau.

In this study the SINTACS method has been improved taking into account the three-dimensional structure and anisotropy of karst by means of a morphological and structural analysis. 


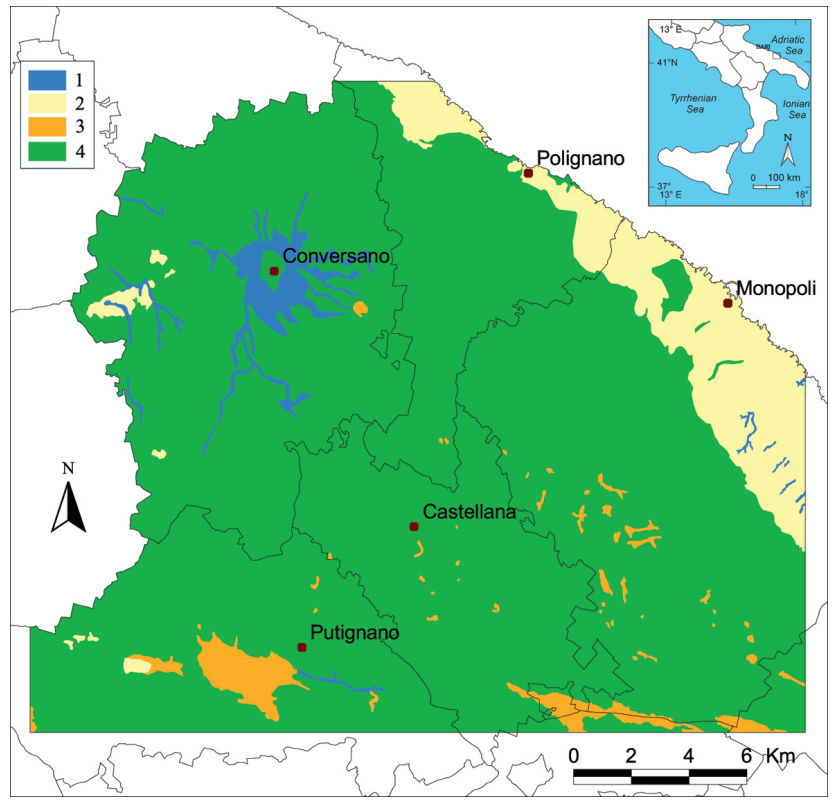

Fig. 1. Geographical location and schematic geological map of the study area: 1) Pleistocene calcarenites, 2) Cretaceous limestone, 3) terra rossa deposits, 4) alluvial deposits.

\section{Geological and morphological setting}

The Murge plateau is the central part of the thick carbonate Mesozoic sequence of the Apulian platform. It consists of a broad highland oriented in a NW-SE direction, with a saddle which divides it into the north-western Murge with a maximum elevation of $680 \mathrm{~m}$ a.s.l and the south-eastern Murge with a maximum elevation of about $500 \mathrm{~m}$ a.s.l. (Boenzi and Caldara, 1991).

Cretaceous carbonate platform deposits outcrop in the Murge area (Ricchetti, 1994). The Cretaceous limestone sequence, known as the "Calcari delle Murge" Group (Fig. 1), is constituted by the "Calcare di Bari" Formation (Middle Cretaceous) and the "Calcare di Altamura" Formation (Upper Cretaceous). The "Calcari di Bari" Formation consists of a thick sequence of mostly detritic limestone layers and some dolomite levels while the "Calcare di Altamura" Formation consists mainly of biogenic fine limestone. The carbonate rocks are overlaid by thin transgressive whitish-yellowish sediment consisting of Tertiary and Lower Pleistocene calcareous organic deposits known as the "Calcareniti di Gravina" Formation (Iannone and Pieri, 1979). In the Holocene, terra rossa deposits from limestone solution and alluvial deposits accumulated in depressed areas such as dolines and river valleys (Merla and Ercoli, 1971).

The actual physical setting of the study area is strongly related to its tectonic history. After a long period of carbonate sedimentation during the Cretaceous, a continental sedimentation followed characterised by several, mostly distensive, tectonic phases (Pieri, 1980). The first and the oldest tectonic phase dissected the carbonate platform into large distinct blocks. The second phase, followed by minor tec- tonic activity, dissected the blocks deeply forming slight Wdipping folds. The morphology which developed during the continentally period and the first karst phenomena are almost identical to today's. Further vertical movements along high angle faults developed a step-like structure dipping NE and SW respectively toward the Adriatic Sea and the Bradanic Trough (Ciaranfi et al., 1988).

During the Middle-Upper Pliocene and Late Pleistocene the area underwent a slow but constant lowering that allowed transgression and sedimentation of the Quaternary succession. Starting from the Middle Pleistocene and for all the remaining Quaternary age the area had a general tendency to be emerged and this allowed the formation of small scarps within the Pleistocene calcarenite deposits (Di Geronimo, 1970). There are generally more then seven ancient coastlines, always parallel to the modern coastline, which outcrop at different height above the sea level. Other sea level oscillations occurred during the Quaternary glaciations; the sea level fell by a maximum of $130 \mathrm{~m}$ during the Würm and returned to its present position almost 5000 years ago.

The whole area is characterised by developed karst landforms which formed a network making the chemical solution of limestone easy (Sauro, 1991; Parise, 1999). Karst formed in response to several morphogenetic phases which took place in different climatic and structural contexts (Grassi et al., 1982; Bruno et al., 1995). As a result an underground network of cavities, caves and conduits is developed; some of these have great dimensions such as the Castellana cave (more than 3000 metres in length) and Pozzo Cucù cave. The landscape is characterised by many dolines, valleys and water lines. Dolines are of different dimensions and they are either quite circular or elongated in one direction; in some cases they are coalescent and they form an endorheic basin. The valleys and water lines are the remnants of the original hydrographic network (Parise 1999) and are mainly directed to the NE. Today karst is exclusively due to rainfall since there is no permanent superficial drainage system in the whole area.

\section{Improvement of SINTACS method}

The SINTACS (Civita, 1994) method was developed to assess intrinsic groundwater vulnerability. Since vulnerability is a function of many system factors the SINTACS method is based on the following seven parameters: depth to groundwater $(\mathrm{S})$, which is the depth of the water table from the topographical surface; effective infiltration (I), which is the amount of rainfall which recharges the acquifer; unsaturated zone attenuation capacity $(\mathrm{N})$ and soil/overburden attenuation capacity $(\mathrm{T})$, which concern the physical and hydrogeochemical processes affecting underground water quality; hydrogeologic characteristics of the aquifer (A) and hydraulic conductivity range of the aquifer (C), which describe the characteristics of the acquifer based on the hydrogeological setting of the bedrock; hydrological role of the topographic slope (S), which concerns the runoff on the topographical 
surface. In order to weight the parameters in assessing groundwater vulnerability, a score from 1 to 10 is assigned to each parameter. Moreover, the SINTACS is designed to use five strings of multiplier weights in order to exalt the parameters on the basis of their relative importance in different contexts. These effective hydrogeological and impacting situations are: normal impact, relevant impact, drainage, karst terrain, fissured terrain. The method has been applied in different geological and hydrogeological contexts giving good results. These tests, carried out since the early 90's, have allowed various improvement, the latest of which is Release 5 (Civita and Di Maio, 2000) which is the evolution of the previous releases. In particular this version has been automated employing widely used hardware and software.

In order to set the SINTACS method for a karst context, in particular that of the Murge carbonate platform with a deep aquifer and a lack of springs, some improvements are suggested. The proposed changes integrate some of SINTACS parameters such as depth to groundwater (S), effective infiltration action $(\mathrm{I})$, unsaturated zone attenuation capacity $(\mathrm{N})$ and soil/overburden attenuation capacity (T). An assessment of the arrangement of effective hydrogeological and impacting situations is also computed by the analysis carried out in this study. The improvements are based on superficial lineaments and karst feature density collected by remote sensing and field work. Dolines mapping (Fig. 2a) was carried out by means of stereoscopic analysis of aerial photographs in order to identify karst depressions on the ground. The multispectral interpretation of satellite images allowed those superficial lineaments (Fig. 2b) characterised by different thermal and soil moisture levels to be mapped (Uricchio and Masciopinto, 1999). Field tests carried out in several sites allowed depressions, caves and lineaments to be checked randomly. All data were implemented in a GIS together with profiles and plans of fifty caves resulting from speleological surveys in the area (for example Bruno et al., 1992; Comes et al., 1992; Fanizzi and Manghisi, 1999; Giuliani, 2000; Savino, 1993; Sgobba, 1995).

$\mathrm{S}$ rating is related to groundwater table depth: the greater the depth, the lower the vulnerability since the thickness of the unsaturated zone reduces pollution due to physical and chemical processes. The protection effect is lost on zones with higher permeability. The improvement in the method consists in reducing groundwater table depth by means of cave depth in order to take into account the voids which facilitate underground pollution. Unfortunately, this procedure has no effect on the S parameter in the study area, since no caves reach groundwater and anyway, the thickness of the carbonate rock corresponds to a lower rating.

The I parameter is based on superficial feature density (both lineaments and dolines) since the type of infiltration depends on superficial karst development and fracture pattern. The calculation of I provides for the assignment of a $\chi$ value (Civita and De Maio, 2000): the $\chi$ rating variation for each lithology is then linked to the arrangement of the superficial feature density.
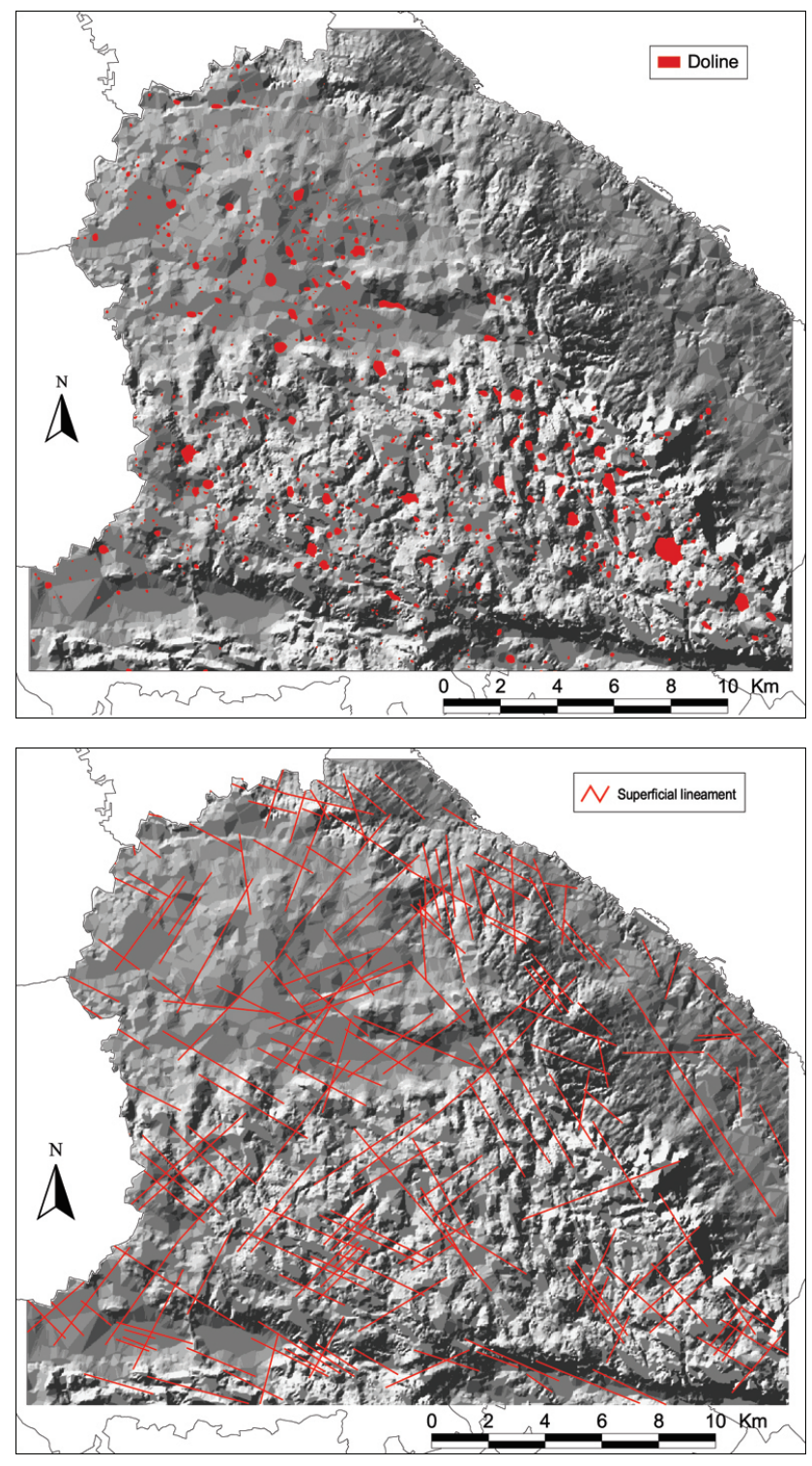

Fig. 2. Digital elevation model of the study area based on the contour lines of the 1:25000 topographical map overlaid by: (a) doline distribution collected by stereoscopic aerial photograph analysis; (b) arrangement of superficial lineaments collected by multispectral analysis of satellite images

In order to assess the $\mathrm{N}$ parameter, the weighted mean rating has to be computed for each cell-based column when the unsaturated thickness consists of several lithotypes. In this improvement the density and shape of caves are taken into account with the maximum rating (10) and they are computed in the same way of a lithotype. Moreover, the assignment of the rating to the other lithotypes is based on the superficial feature density.

The modification in the $\mathrm{T}$ parameter calculation refers to an increase of the rating which is fixed higher than that established by the authors (Civita and De Maio, 2000) since the soil is very thin in the karst. Data on soil thickness were collected by the ACLA Project (Regione Puglia, 2001), 

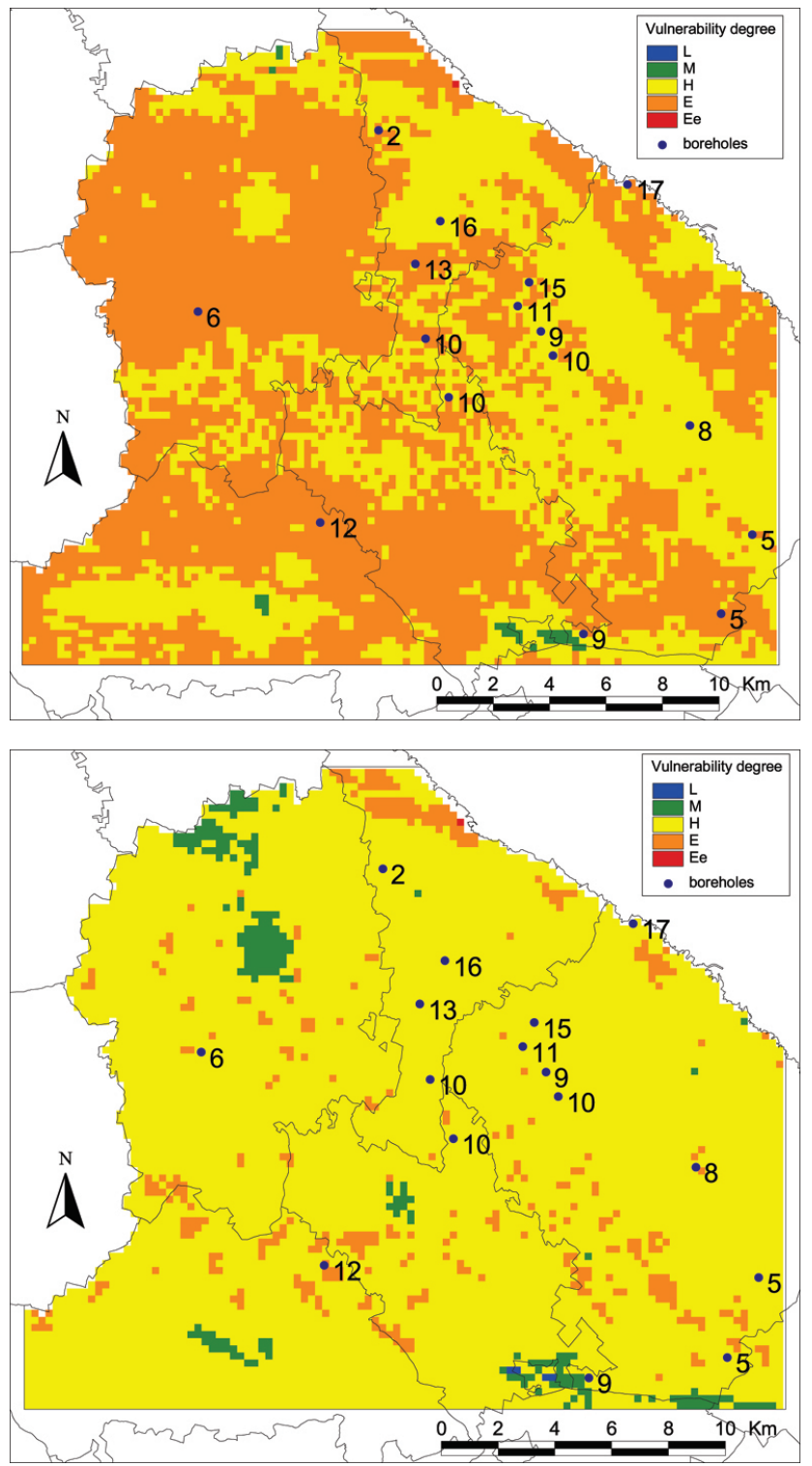

Fig. 3. (a) Intrinsic vulnerability index arrangement resulting from the application of the SINTACS R5 method without the improvements proposed; (b) intrinsic vulnerability index arrangement carried out using the proposed procedure based on the analysis of superficial lineaments and karst feature distribution. The degree of vulnerability ranges from low $(\mathrm{L})$, to medium $(\mathrm{M})$, high $(\mathrm{H})$, elevated (E) and extremely elevated (Ee). The location of each borehole in which the groundwater nitrate concentration $(\mathrm{mg} / \mathrm{l}$, values rounded to the nearest whole number) was measured, is plotted in the SINTACS maps.

a database containing an extensive soil survey aimed at the characterization of Apulia soils.

To assess the effective hydrogeological and impacting situations, the karst and fractured zones are determined according to the highest karst and lineament density and based on those areas with relevant human impact according to the land use of the CORINE Land-Cover map (JRC, 1995).
All these procedures are performed in a GIS which made the SINTACS process easy by mean of ArcGis ${ }^{\circledR} 8.2$ Spatial Analyst (Marsico, 2003). In fact, complex conditions are stated using Raster Calculation ${ }^{\circledR}$ functions in order to take into account both ground features and their distribution and the density values during the calculation of parameter variations in the area.

\section{Results of improved method}

The study was performed in order to compare the results of the original method (Civita and De Maio, 2000) with those of the modified method. Two maps were drawn as a result of the application of the two procedures. The map drawn up by SINTACS R5 without improvement assesses mainly an elevated degree (E) of intrinsic vulnerability (Fig. 3a) while the modified method assesses a high degree $(\mathrm{H})$ almost everywhere (Fig. 3b). The original SINTACS R5 index ranges between 131 and 211, the mean value is 185 with a standard deviation of 9,68 which indicates a poor variability. The modified SINTACS index ranges from 102 to 214 with an average value of 170 and the standard deviation is 13,51. Even if the latter standard deviation suggests that the pixel values are more scattered than those of the original method, most of these pixels ranges between 141 and 186 which indicates high vulnerability (Civita and De Maio, 2000) that is to say less vulnerability with respect to the original SINTACS. This consideration is confirmed by the average values. Moreover, the karst features and superficial lineaments have spread the values of the vulnerability index, showing a greater sensibility to the specific features of the studied area.

In order to assess the reliability of the modified method several comparisons were made. First of all, the results of both SINTACS index maps were compared with known karstic and structural features in the area. Therefore, the two SINTACS index maps were overlaid by the karst and superficial lineament distributions. Figure $4 \mathrm{~b}$ shows the overlay of the karst and structural features on the modified index arrangement; Fig. 4a shows the same features on the unmodified SINTACS index. The former figure shows a good correlation between the specific features of the studied area and the highest values of the vulnerability index; this good correlation is evident for the dolines and caves, which are point karst features, as well as for superficial lineaments, which are diffuse structural features. Point features increase the values of the vulnerability index more than diffuse ones. The original SINTACS R5 index, on the other hand, although higher than the modified one, does not agree with the feature arrangement (Fig. 4a). The use of such features is a useful tool for improving the knowledge of the territory and setting up an appropriate methodology to define the vulnerability of the area.

In order to confirm the reliability of the modified method, both SINTACS maps were compared with groundwater nitrate concentrations which were measured in certain wells. The high concentration values indicate a fast flow rate and 

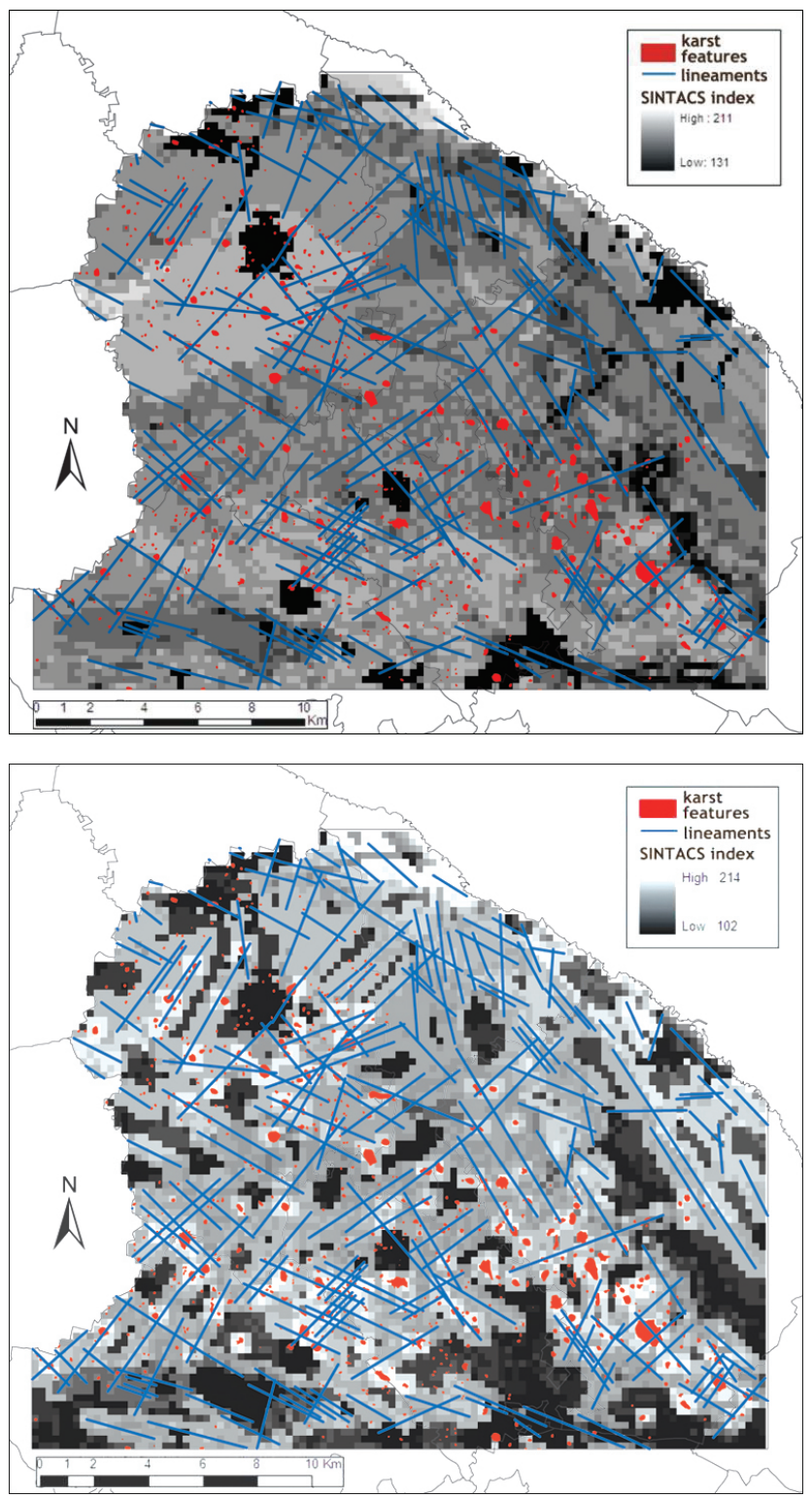

Fig. 4. Grey scale variation of SINTACS R5 index overlapped by superficial lineaments and karst features (both doline and cave plans) mapped in the area; (a) original SINTACS R5 index variation which does not agree with the features mapped; (b) modified SINTACS index well related with the features mapped in the area

a poor protection provided by soil and by the karst bedrock. The overlaps show that the highest nitrate concentration values agree better with intrinsic vulnerability index arrangement of modified method (Fig. 3b) than with that of original SINTACS R5 (Fig. 3a). That is to say that the modified procedure takes into account the enlarged fractures and the swallow holes which allow polluted water to have easy access to the groundwater.

All these comparisons confirm that the modified SINTACS index is suitable for the karst area studied, since it shows a closer correlation with its geological and hydrogeological characteristics.

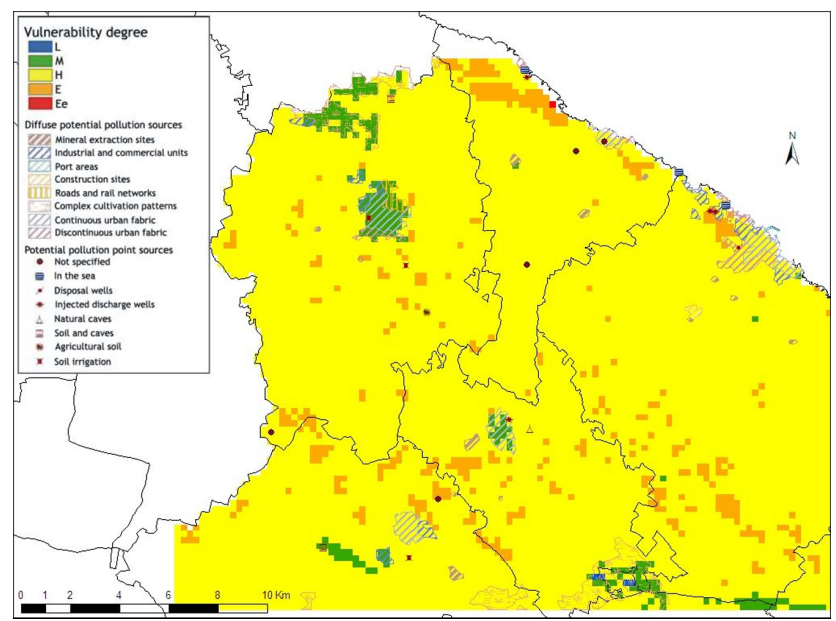

Fig. 5. The final vulnerability map of the study area was produced by combining the best fitting modified SINTACS map with the layout of potential pollution centres. Diffuse potential pollution centres were reported by the CORINE Land-Cover project, while the potential pollution point sources were extracted from the authorized discharge database of the Environmental Division of Bari Province. The degree of vulnerability ranges from low (L) to extremely elevated (the same as in Fig. 3).

\section{Conclusion}

Assessing intrinsic vulnerability in karst areas is difficult since the stage and type of development of karst structure and underground discharge behaviour are not easy to determine. The integration of a SINTACS procedure with analyses carried out on the distribution of dolines, caves and superficial lineaments makes the method suitable for karst areas. In this study, the assessment of some SINTACS parameters was based on the density of karst and structural features collected by remote sensing and field work. The system was implemented in a GIS which makes several steps easy and allows new queries to be created and conditions for the analysis to be stated. The original SINTACS R5 was also processed in the same area in order to compare results with those of the modified procedure. The results of both SINTACS index maps were compared with karst and structural features identified in the area and with the groundwater nitrate concentrations in some wells. These comparisons confirm the reliability of the modified SINTACS map which can be used to describe the intrinsic vulnerability of the area studied. Finally, Fig. 5 shows this best fitting map overlaid by diffuse and point potential pollution centres collected for this area. These data concern mines, industrial and urban areas, intensively cultivated sites and discharges through wells and natural shafts. This map provides for a complete picture of the pollution risk in the area and making a contribution to environmental protection and management policy of natural resources. 


\section{References}

Ricchetti, G. (Ed): Guida all'escursione tematica sul Cretaceo murgiano, Congresso Nazionale "Geologia delle aree di Avampaese", 23 settembre - 1 ottobre 1994, 86 pp, 1994.

Aller, L., Bennet, T., Lehr, J. H., and Petty, R. J.: DRASTIC: a standardised sustem for evaluating groundwater pollution potential using hydrologic setting, US EPA Report, 600/2-87/035, Robert S. Kerr Environmental Research Laboratory, Ada, OK, 1987.

Boenzi, F. and Caldara, M.: Appunti sul paesaggio carsico pugliese, Itinerari Speleologici, serie II, 4, 17-30, 1991.

Bruno, G., Del Gaudio, V., Mascia, U., and Ruina, G.: Numerical analysis of morphology in relation to coastline variations and karstic phenomena in the south-eastern Murge (Apulia, Italy), Geomorphology, 12, 313-322, 1995.

Bruno, G., Savino, G., and Sciortino, A. A.: Considerazioni idrogeologiche sulle grotte di Pozzo Cucù (Puglia) desunte dal trattamento statistico di forme carsiche. Atti del II Convegno di Speleologia Pugliese, 91-98, 1992.

Ciaranfi, N., Pieri, P., and Ricchetti, G.: Note alla carta geologica delle Murge e del Salento (Puglia centromeridionale), Mem. Soc. Geol. It., 41, 449-460, 1 tav, 1988.

Cimino, A. and Abbate, R.: A methodological approach to the hydrogeological risk assessment in a karst region, The great urban area of Palermo (Western Sicily), Colloque européen, Karst 99, Etudes de géographie physique, suppl. XXVIII, 67-72, 1999.

Civita, M.: Le carte di vulnerabilità degli acquiferi all'inquinamento: teoria e pratica, Quaderni di tecniche di protezione ambientale, Pitagora ed., 326 pp., 1994.

Civita, M. and De Maio, M.: Valutazione e cartografia automatica della vulnerabilità degli acquiferi all'inquinamento con il sistema parametrico SINTACS R5, Pitagora Editrice Bologna, pp. 226, 2000.

Comes, P., Garganese, V., and Rotondo, D.: La grave di Santa Lucia in agro di Monopoli (Bari), Itinerari Speleologici, 1992, II, 6, 55-78, 1992.

COST Action 65: Karst groundwater protection, Final report, European Commission Report EUR 16547en, 349-445, 1995.

Cucchi, F., Forti, P., and Zini, L.: The vulnerabilità of complex karst hydrostructures: problems and prospectives. Proceeding of the First International Workshop on Aquifer Vulnerability and Risk, Salamanca, Guanajuato, Mexico Mayo, 28-30, 50-59, 2003.

Cucchi, F., Martinetti, E., Massari, G., and Zini, L.: Carta della vulnerabilità intrinseca dell' acquifero carsico triestino e isontino, Le grotte d'Italia, 1, 21-31, 2000.

Di Geronimo, I.: Geomorfologia del versante adriatico delle Murge di SE (zona di Ostuni, Brindisi), Geol. Rom., 9, 47-57, 1970.

Doerflinger, N. and Zwahlen, F.: Groundwater vulnerability mapping in karstic regions (EPIK), Practical Guide, Swiss Agency for the Environment, Forest and Landscape, Berne: 56 pp, 1998.

Fanizzi, A. and Manghisi, V.: La grotta di S. Antonio (o di Monsignore) nel territorio di Conversano (Ba), Pugliagrotte 1999, 53-60, 1999.
Foster, S. S. D.: Fundamental concepts in aquifer vulnerability, pollution risk and protection strategy, in: TNO Committee on Hydrological Research, the Hague, Proceedings and Information, edited by: van Duijvenbooden, W. and van Waegeningh, G. H., 38, 69-86, 1987.

Giuliani, P.: Elenco delle grotte pugliesi catastate fino al 31 ottobre 1999, Itinerari Speleologici, 9, 5-42, 2000.

Grassi, D., Romanazzi, L., Salvemini, A., and Spilotro, G.: Grado di evoluzione e ciclicità del fenomeno carsico in Puglia in rapporto all'evoluzione tettonica, Geol. Appl. e Idroegeol., vol. XVII, 55-73, 1982.

Iannone, A. and Pieri, P.: Considerazioni critiche sui "Tufi Calcarei" delle Murge - Nuovi dati litostratigrafici e paleoambientali, Geogr. Fis. Dinam. Quat., 21, 33-58, 1979.

Joint Research Centre (JRC): CORINE Land Cover, Ispra, 1995.

Longo, C. A., Andreo, B., Carrasco, F., Cucchi, F., Vias, J., and Jiménez, P.: Comparison of two contamination vulnerability maps obtained by the SINTACS method in two carbonate aquifers (S Spain), Sciences et Techiniques de l'Environnement, Université de France-Comté, mémoire hors-série, 13, 233-236, 2001.

Malìk, P. and Švasta, J.: REKS - An alternative method of karst groundwater vulnerability estimation, Hydrogeology and Land Use Management, XXIX Congr. of the Intern. Assoc. of Hydrogeol., Bratislava 1999, Proceedings: 79-85, 1999.

Marsico, A.: Valutazione dell'impatto antropico sui sistemi carsici: la vulnerabilità dell'acquifero delle Murge Sud-Orientali, Tesi di dottorato, Università di Bari, 183 pp., 2003.

Merla, G. and Ercoli, A.: Note illustrative della Carta Geologica, Foglio 190, Monopoli. Serv. Geol. Ital., Roma, 23 pp., 1971.

Parise, M.: Morfologia carsica epigea nel territorio di Castellana Grotte, Itinerari Speleologici, 8, 53-68, 1999.

Petelet-Giraud, E., Doerflinger, N., and Crochet, P. : Evaluation multicritère de la vulnérabilité des aquifères karstiques en région méditerranéenne à l'aide de la méthode RISKE (Karst Nord Montpelliérain), 7th Conference on Limestone Hydrology and Fissured Media, Scinces et Techniques de l'Environnement, Université de Franche-Comté, mémoire hors-série no.13, 281-284, 2001.

Pieri, P.: Principali caratteri geologici e morfologici delle Murge, Boll. Gr. Spel. Martina "Murgia Sotterranea”, II, 2, 13-19, 1980.

Progetto ACLA: Caratterizzazione agro-ecologica della regione Puglia e classificazione del territorio in funzione delle potenzialità produttive, A cura dell' Assessorato Agricoltura e Foreste della Regione Puglia, 1999.

Savino, G.: Esplorazioni in territorio di Castellana-Grotte e Monopoli, Pugliagrotte, 21-24, 1993.

Sauro, U.: Il carsismo delle Alte Murge (Puglia, Italia), Itinerari Speleologici, 5, 67-71, 1991.

Sgobba, D.: Torre di Mastro: una grotta da non dimenticare, Pugliagrotte, 59-65, 1995.

Uricchio, V. F. and Masciopinto, C.: Riconoscimento semiautomatico delle linee preferenziali di scorrimento d'acqua da immagini satellitari, Acque Sotterranee, n.3 Fascicolo 63, 63-71, 1999. 